\title{
PUBLIC DIPLOMACY DURING CRISES AND CONFLICTS: THE COVID-19 CHALLENGE
}

\author{
Ecaterina Hlihor ${ }^{1}$ \\ "Carol I" National Defence University
}

\begin{abstract}
The spectacular evolution in communication technology, and not only, enabled the world to achieve today a high degree of interconnectivity and interdependence that would have been hard to fathom only a couple of decades ago. The economic, political and, alas, health crises swiftly cross political, cultural and religious borders and yield consequences not only where they appear. This phenomenon forces national institutions and international organizations to communicate with the public opinion at a transnational level, a process also achieved through public diplomacy. The present article suggests a framework of action in which public diplomacy may be used as an instrument of communication in the case of crisis provoked by the Covid-19 pandemic. The current period of time is seen as a critical moment, a crisis that can permanently shatter institutions and societies. There are considerable dangers beyond the impact of the pandemic on people's lives, ranging from an economic crisis that might prove more serious than the one in 2008/9, to an accentuated crisis of democracy and geopolitical changes, while public diplomacy could mitigate or eliminate these possible evolutions.
\end{abstract}

Keywords: globalization; crisis; public diplomacy; Covid-19; transnational communication.

\section{INTRODUCTION}

The corona virus epidemic seems to affect the course of universal history through its consequences manifesting as a genuine turning point not only in the medical field, but also in those of economy, finance and trade, as well as in that of international affairs. Examples in recent decades demonstrate that each exceptional event at international level, regardless of it occurring at a technological (the explosion of the Chernobyl nuclear reactor, the chemical accident in Bhopal, the nuclear meltdown in Fukushima etc.), environmental (Hurricane Katrina, the drought in the Sahel etc.), or societal level (the fall of the Berlin Wall and the collapse of the communist regimes, the 2008/2009 financial crisis, the crises in North Africa known as the Arab Spring), acted as a historical marker in the collective psychic and led to major changes at the level of each individual society and of humanity as a whole. The current pandemic caused by the virus contracted the economic activity at global level so that analysts compared this period with that of the Great Recession in 1929-1933 of the past century when, among other consequences, unemployment reached un unseen before level in the world's modern and contemporary history (lacurci 2000). At the same time, Covid-19 exacerbated national rivalries in many domains where states used to cooperate. It emphasized, especially in the Western (American) society, racial frictions, while socio-economic inequalities were accentuated, like between urban and rural communities. Many aspects of the Covid-19 pandemic and the response to them were heavily politicized in many countries regarding the acceptance or rejection of governmental measures to contain the situation, like the compulsory wearing of a face mask or the observation of a number of rules which affect/limit a number of freedoms specific to liberal and democratic societies. Only a decade ago, until the beginning of the Covid-19 pandemic, all collective efforts have been dedicated to the creation of a civil global society "steeped in American-oriented values: democracy, human rights, and social, political, and economic liberalism" (Arquilla \& Ronfeldt 1999, 65-66). Such rhetoric of global interconnection, considered as a key factor in the use of public

${ }^{1}$ Corresponding author: hlihor.ecaterina@myunap.net 
diplomacy in the whole world, was put under question by the pandemic through the measures taken by governments at local level in order to limit the circulation of people and goods.

All these sparked an avalanche of questions that sit on everybody's lips, from ordinary citizens to politicians, from entrepreneurs and doctors to analysts and researchers in various fields (security, internal policy, foreign policy, public diplomacy etc.). How will the measures to contain the pandemic affect the role and especially the mechanisms of functioning of the institutions and organizations involved in managing foreign policy, including the health ones, at regional and global levels? Will the pandemic de-values classical institution and their specific instruments in the struggle for hegemony and control and will it accentuate the role of those capable of effectively using soft power? Will there be an increase of the role of public diplomacy in the current global health state? What types of public diplomacy messages are functional and effective in such situations? Which is the channel through which public diplomacy could demonstrate its effectiveness, having in mind that its classic type activities, like face-to-face meetings, are suspended in most countries? These are only a couple of the questions to which we will try to find the answer.

\section{THE IMPACT OF THE COVID-19 PANDEMIC ON FOREIGN POLICY}

The pandemic caused by the Covid-19 virus emphasized the fact that nowadays, due to the unprecedented development of the means of communication, a number of social phenomena manifest themselves a lot more intensely, without being fundamentally different from what people "experienced" in the case of other epidemics or pandemics. Perceptions on the pandemic occurring one hundred years ago are relevant to this end. When the 1918 flu pandemic started spreading in a world still at war, the warring nations quickly blamed and accused each other for front trenches lacking proper hygiene facilities, over-populated medical camps, non-hygienic transportation of the troops etc. But these factors existed and manifested themselves on all belligerents, accusers and accused alike (Simms 2018). As the spread of the Covid-19 virus became global, Western media and American leaders emphasized "the initial failure by China to contain the virus and to prevent the spread of the pandemic" (Emerging Views 2000). In their turn, the Chinese not only rejected the accusations, but they also formulated the same type of accusations against the Americans (Winter 2020). How can we overcome such situations in the preset society? Why, after a century of evolution in knowledge and development of medical security, reactions and situations like those generated by the Covid-19 seem to repeat themselves, only with other actors and along different geopolitical coordinates? Could answers to these questions be found? The possible answers can be found within an extremely wide range, from negation to affirmation.

Sceptics favour the truth that each pandemic that took place in the past was different than the preceding one, something which proves to be true in the case of the current pandemic. For these, the medical staff and public administration staff at all levels must take action on the "frontline", and not other categories of specialists. Without categorically dismissing such a prejudice, we believe that it would be useful to study the way in which people reacted in pandemic situations in the recent or remote past (Bergdolt 2012, 11-12). Referring to the lessons that could be learned by researching the "Spanish Flu" that caused so many victims in 1918-1919, Professor Stephen S. Morse from Columbia University, New York wrote more than a decade before the Covid-19 pandemic: "That historical data from 1918 keep even today such utility is both a demonstration of the value of history and a great irony in itself. The irony happening now, almost 90 years after the gravest pandemic in recorded history, is that we still do not have a full understanding of the fundamental aspects of flu transmission, so that we have to rely on century old empirical results. A lot more research is clearly necessary in order to better understand flu epidemiology and transmission, to project useful interventions and to develop the technology to quickly and effectively manufacture the necessary vaccines" (Morse 2007). The lessons of the past and the geopolitical projections can also be useful in understanding the crises provoked in modern society by various viruses and other pathogens, as they are used in other domains of human experience, such as wars and hegemonic rivalries in the international arena.

On 14 April 2020, Condoleezza Rice, former US State Secretary and national security advisor to the Bush administration, stated in a press conference at the Hoover Institute that international 
institutions did not respond effectively to the Covid-19 crisis. However, individual countries responded on their own, without cooperation or coordination (Rice 2020). This led to the emergence of fierce competition between international actors, each looking to enhance its advantages in relation to the others, even if the need for cooperation against the virus required another type of behaviour. From a different perspective, if we look back in the recent history, we will observe that this type of behaviour recently seen in the case of the SARS-COV 2 crisis is not singular. In the past, countries like Russia exploited similar crises, using them against the United State, including the HIV/AIDS epidemic in the 1980s (Boghardt 2009). Iran and Russian sponsored mass-media constructed a series of conspiracy theories about the United States and SARS-COV-19 and promoted criticism regarding the measures by the Trump Administration to combat the pandemic (Chernaskey 2020). Both China and Russia used he pandemic to re-enforce their image in the international arena by providing medical assistance to a number of states in difficulty, as it was the case of Italy, but this, in the opinion of specialists, seems rather to have been a geopolitical gain than an act driven by humanitarian reasons (Braw, 2020). In these strategies of competition at regional or global levels, the instruments of soft power, among which public diplomacy, played an enhanced role through an effort of accommodation and adequateness to a society in a pandemic situation.

\section{PUBLIC DIPLOMACY DURING THE COVID-19 PANDEMIC}

The Covid-19 pandemic influenced both the international environment and the instruments through which states consolidate their image or enhance their influence in order to be able to impose their interest at regional or global level. One of the ways through which states try to shape their foreign policy is public diplomacy because it mainly, but not exclusively, addresses certain target groups in other societies and has more credible instruments than the official ones so that the message reaches them. To this end, professionals and analysts in the field of public diplomacy quickly adapted to the situation created in the world by SARS COV2. The efforts of the state institutions grew in order to create facilities for the promotion of its interests through public diplomacy. Through various measures, in support of their external actions, they attracted the support of international non-state actors like big manufacturers of pharmaceutical equipment and products. From this perspective, the observation by a number of analysts that internal public diplomacy overlaps with "a specific governmental public relations function" (Signitzer \& Wamser 2006, 435-464) seems to have been confirmed during the Covid-19 pandemic. Upon summary analysis, we can state that up to now China has exploited this opportunity. According to analyst Raj Verma, this public diplomacy campaigned carried out by China has also involved non-state actors. Researching this phenomenon, Raj Verma noticed that "Chinese multinational corporations have also indulged in "mask diplomacy". It is not completely clear whether this is at the behest of the Chinese government. The Alibaba Foundation and the Jack Ma Foundation have already provided medical assistance to France, Spain, Italy, Belgium, Ukraine and other counties. Jack Ma Foundation has also published a handbook to help countries fight COVID-19. Huawei has also provided testing kits and masks to Italy, Ireland, Spain, Poland, Czech Republic and the Netherlands. Oppo, Xiaomi and other Chinese smartphone companies have also sent thousands of masks to European countries" (Verma 2020, 205-209). China provided medical assistance and sold ventilators, other intensive care facilities, masks, gloves, test kits and medication to numerous European countries. It sent medical experts and shared medical expertise with France, Italy and the "17+1" group countries in Central and Eastern Europe (CEEC). The Chinese assistance was positively appreciated in most European countries. Thus, some of the officials of the countries where China sent aid became "agents of influence" of the Chinese public diplomacy. A relevant example is that of the Hungarian prime-minister, Viktor Orban, who "personally welcomed the arrival of a plane from China at Budapest airport, noting that 86 planes had arrived up to 24 March with masks, tests and ventilators" (Szicherle \& Krekó 2020). A genuine war of public statements ensued in Hungarian mass-media regarding the battle for public standing between proEuropeans and pro-Chinese in Budapest. On a different note, the cabinet and its media did not present important information about the equipment Hungary bought. For instance, the quality issues with Chinese-manufactured masks were never raised towards China, even though the government in 
Beijing had to take action against shoddy masks itself. In contrast, Zoltán Kovács noted on Twitter that the masks distributed by the EU "are of such low quality that they are of little use." He did, however, forget to mention that those masks were purchased from China. The price of the equipment was not mentioned either. Overall, the government made Beijing look like a charity instead of a business partner" (Szicherle \& Krekó 2020).

Nevertheless, China was the one who used the andemic situation in order to create perception advantages for itself in the international arena. The Chinese diplomacy tried to discredit some states by showing and exaggerating their difficulties in combating the pandemic and solving the public health crisis. It demonstrated its determination to impose its own narrative both at European and global level. The Chinese narrative was conceived in order to counter what is perceived as Western hostility, given the criticism by the USA regarding the Chinese lack of transparency at the onset of the pandemic. This aggressiveness took the form of doubts expressed on tweets to Chinese diplomats regarding the origins of the epidemic. A true war of messages was carried out between China and the great Western powers through tactics specific to public diplomacy, each side seeking to convince the public opinion about which state was guilty of the spread of the Covid-19 pandemic. For example, "Inside China, a raft of conspiracy stories have appeared online, including that the contagion might have been brought in by American athletes staying in Wuhan during the Military World Games last year" (Austin \& Smith 2020). We must underline the fact that during this period China, as well as the Russian Federation, used its previous "mask diplomacy" experience gained while intervening to help states affected by other pandemics. In 2009, it used "mask diplomacy" in Mexico during the $\mathrm{H} 1 \mathrm{~N} 1$ flu in order to have itself described as a benevolent nation (Browne 2009) in order to counterbalance the attractive image enjoyed by the USA in this country. China applied the same tactic at the beginning of February 2021, when "half a million doses of the Chinese Sinopharm COVID-19 vaccine arrived in Pakistan, before soon also reaching 13 other countries including Cambodia, Nepal, Sierra Leone and Zimbabwe. The Chinese ambassador to Pakistan declared it a "manifestation of our brotherhood", a sentiment echoed by the Pakistani government" (Khan 2021).

Neither did the Russian Federation miss the chance to use the opportunities generated by the pandemic on order to re-enforce its public diplomacy in Western areas of interest or in other regions of the world. Although the Russian authorities were confronted with growing difficulties in managing the pandemic, "On April 1, Russia sent humanitarian aid to the United States. The massive cargo aircraft, an Antonov An-124 Ruslan, took off from the Chkalovsky military airport near Moscow bound for the U.S., landing in New York City's JFK airport on the same day. The aircraft was filled with medical equipment and protective gear including medical masks to help Americans in fighting COVID19. Russia's initiative resulted from a prior telephone conversation between Putin and Trump. Earlier on March 22 as a gesture of goodwill, Russia sent medical assistance to Italy amid the country's struggle with the pandemic. Russia also sent medical military aid to Serbia to fight corona virus" (Krasnyak 2020). It is interesting to note that, in order to be more easily promoted through public diplomacy, the vaccine for the protection of the population against the SARS COV2 virus was named Sputnik V, which "alludes to the world's first space satellite that the Soviet Union launched in 1957" (Budnitsky 2020). The promotion of this vaccine is done on a website edited in no less than eight languages and it offers "a press kit with photos, videos, and graphics for anyone wanting to cover the initiative. As the site explains of Russia's reputational goals, "In 1957 the successful launch of the first space satellite Sputnik-1 by the Soviet Union reinvigorated space research and exploration around the world. The announcement of the new Russian COVID-19 vaccine created a so-called 'Sputnik moment' for the global community. The vaccine is therefore called Sputnik V" (Budnitsky 2020). According to Chatham House experts, "The Kremlin's economic response to COVID-19 has been modest compared to many of its rivals. Although the government is under increased pressure to spend its 'rainy-day fund', it believes that doing so will ultimately undermine the fiscal stability underpinning its geopolitical sovereignty" (Chatham House 2020). This fact influence the quality, attractiveness and credibility of the Russian public diplomacy conducted in various spaces during the Covid pandemic. As a matter of fact, there are experts who noticed that the Coronavirus pandemic 
has had little visible effect on Russian foreign policy, except the fact that it strengthened its fundamentals (Lo 2020).

The breakout of the COVID-19 pandemic activated channels of so-called "aid diplomacy". By aid diplomacy, I mean a sub-type of public diplomacy that concentrates on the distribution of aid as one of its primary strategies. The spread of the virus at the end of 2019 and the first half of 2020 made people understand that this global issue could not be solved individually by a single country. Even for China, producing a sufficient quantity of masks at the peak of the coronavirus was more than a challenging task to complete; thus, China acquired masks from abroad. Other countries with even lesser production capabilities equally could not meet the demand during their own peaks either (Varpahovskis 2020).

The main preoccupations of Western public diplomacy institutions and organizations, mainly those in the EU, USA, Great Britain, Canada, Australia etc, was to make functional a connecting bridge between societies and to combat the disinformation carried out through public diplomacy strategies and tactics by China, the Russian Federation and other illiberal or authoritarian states (Bishop 2020). Naima Green-Riley believed that "America's strength is its openness. In order for such a truth to persist, it will be important to manage the threat posed by public diplomacy from influenceseeking authoritarian states such as China by pursuing four main policy goals, namely: (1) comprehensive monitoring of the tools of public influence employed by these states; (2) a wellinformed citizenry; (3) an information environment in which knowledge consumers have access to details about the origins of narratives and news; and (4) a values-based approach to confronting authoritarian outreach to the U.S. public. Pursuing such goals should allow the United States to exercise the appropriate caution to ward off unwanted exploitation of its openness while also staying true to its ideals." (Green-Riley 2020,63)

The Western states adapted their public diplomacy strategies in accord with the rules imposed by the sanitary measures meant to contain the pandemic. The dynamic was not modified, because public diplomacy is in essence a set of activities focused on communication, but solutions were identified to preserve the previous parameters. So that digital information to the target audience became an objective promoted by the EU member states, as well as the USA, NATO etc, because a huge growth of the time spent by people online during locally or nationally imposed quarantines had been observed. From this perspective, most of public diplomacy activities have been carried out online through the social networks. The Facebook pages of the embassies of these countries in various parts of the world provided real-time information related to the efforts made to discover vaccines in order to combat the pandemic, and also the achievements obtained in managing serious illnesses. Such an example is that of the US Embassy in Georgia. "American Story Time," a digital public diplomacy program launched by the U.S. Embassy Tbilisi in March 2020, immediately reached its target society by prioritizing manifestly its principal goal: to help Georgian youth learning English as education institutions remained closed and moved online. Going live on Facebook - alone or with family members - to read American stories starting from The Lorax by Dr. Seuss to The Gift of Nothing by Patrick McDonnell and more, American diplomats coordinated efforts to spread authentically the image of the United States, its culture and society in the best ways possible. In addition of being an enjoyable activity, each story time increases understanding of American values (Khatiashvili 2020).

\section{CONCLUSIONS}

The promotion of public diplomacy in the online environment provides important advantages compared to classical manifestations. Analysts like Corneliu Bjola and Ilan Manor believe that "All the while citizens are online comparing their nation's handling of the crisis, to that of other nations. Herein lays an opportunity. Indeed, diplomats can now use social media to document their nations' successful efforts to contain the coronavirus outbreak while holding true to national values" (Bjola \& Manor 2020). The pandemic severely tested the capacity of democratic societies to maintain confidence in its fundamental values through effective communication, to protect the national image of their countries as the crisis escaladed, and to counter the digital disinformation spread by non- 
democratic regimes or non-state actors with obscure interests. At the same time, it showed the necessity that all public diplomacy institutions and organizations, once the pandemic is over, draw the appropriate lessons, learn how to think digitally without prejudice and begin to update their digital expertise, instruments and strategies in order to be better prepared to face the next global crisis which may come about sooner than expected.

\section{REFERENCES}

Arquilla, John, Ronfeldt, David. 1999. The emergence of noopolitik: Toward an American information strategy, RAND, Santa Monica CA.

Austin, Henry, Smith, Alexander. 2020. Coronavirus: Chinese official suggests U.S. Army to blame for outbreak, in News, March 13, 2020. Accessed February 20, 2021. https://www.nbcnews.com/news/world/coronavirus-chinese-official-suggests-u-s-army-blame-outbreakn1157826

Bergdolt, Klaus. 2012. Ciuma. Istoria morţii negre. Translated by Maria Cătălina Radu. Bucureşti: Editura ALL.

Bishop, Donald M. 2020. Disinformation Challenges in a Pandemic. Public Diplomacy Council. Accessed February 26, 2021. https://www.publicdiplomacycouncil.org/2020/07/10/ disinformation-challenges-in-a-pandemic/

Bjola, Corneliu, Manor, Ilan. 2020. Digital Diplomacy in The Time of The Coronavirus Pandemic, USC Center on Public Diplomacy, Mar 31. Accessed February 26, 2021. https://uscpublicdiplomacy.org/blog/digital-diplomacy-time-coronavirus-pandemic

Boghardt, Thomas. 2009. Soviet Bloc Intelligence and Its AIDS Disinformation Campaign. Studies in Intelligence vol.53, no. 4, 2009. Accessed February 20, 2021. https://digitallibrary.tsu.ge/ book/2019/september/books/Soviet-Bloc-Intelligence-and-Its-AIDS.pdf

Braw, Elisabeth. 2020. Beware of Bad Samaritans. Foreign Policy, 30 March 2020. Accessed February, 19, 2021. https://foreignpolicy.com/2020/03/30/russia-china-coronavirus-geopolitic

Browne, Andrew. 2009. China Forces Dozens of Mexican Travelers Into Quarantine. The Wall Street Journal, May 4, 2009. Accessed February 20, 2021. https://www.wsj.com/articles/ SB124137876507580987

Budnitsky, Stanislav. 2020. The Politics Of Russia's Vaccine Promotion, USC University of Southern California, Sep 29, 2020. Accessed on February 20, 2021. https://u.scpublicdiplomacy.org/ blog/politics-russias-vaccine-promotion

Chatham House, Russian Economic Sovereignty in the COVID-19 Age, June 11, 2020. Accessed February 20, 2021.

https://www.chathamhouse.org/2020/06/russian-economic-sovereignty-covid19age?gclid= CjwKCAiA1eKBBhBZEiwAX3gqlz63tB1jHsautHBRSh_6SdxnilQ017jlxYn OPIK13FW7hHja2yqbrBoCYE4QAvD_BwE

Chernaskey, Rachel. 2020. Iranian, Chinese, and Russian Overt Media on Coronavirus, Foreign Policy Research Institute, 9 March 2020. Accessed February 20, 2021. https://www.fpri.org/fie/overt-media-on-coronavirus/

Emerging Views and News on China's Role in the COVID-19 Pandemic. 2020. Occasional News Wrap - \#18/April 2020. Accessed February 22, 2021. http://cuts-wdc.org/pdf/emerging-viewson-chinas-role-in-the-covid-19-pandemic.pdf

Green-Riley, Naima. 2020. Can Public Diplomacy Survive Increasing U.S.-China Friction? Thoughts on Mitigating the Threat of Sharp Power. Leah Bitounis and Niamh King, eds., Domestic \& International (Dis)Order: A Strategic Response, Foreword by Joseph S. Nye, Jr. and Condoleezza Rice. Preface by Nicholas Burns and Anja Manuel. Washington DC: The Aspen Institute. 
lacurci, G. 2020. Unemployment is Nearing Great Depression levels. Here's How the Eras are Similar - and Different. CNBC, 19 May 2020. Accessed February 22, 2021. https://www.cnbc.com/2020/05/19/unemployment-today-vs-the-great-depression-how-do-theeras-compare.html

Khatiashvili, Mariami. 2020. Pandemic-Time U.S. Public Diplomacy in Georgia. USC Center on Public Diplomacy. Accessed February 26, 2021. https://uscpublicdiplomacy.org/blog/pandemic-timeus-public-diplomacy-georgia

Khan, Stephen. 2021. Vaccine diplomacy: how some countries are using COVID to enhance their soft power. The Conversation. February 22, 2021. Accessed February 27, 2021. https://theconversation.com/vaccine-diplomacy-how-some-countries-are-using-covid-toenhance-their-soft-power-155697

Krasnyak, Olga. 2020. For Common Good: Russia's Public Diplomacy During the Covid-19 Era. USC University of Southern California. Apr 17, 2020. Accessed February 20, 2021. https://uscpublicdiplomacy.org/blog/common-good-russia\%E2\%80\%99s-public-diplomacyduring-covid-19-era

Lo, Bobo. 2020. Global Order in the Shadow of the Coronavirus: China, Russia and The West. Lowy Institute. Accessed February 20, 2021. https://www.lowyinstitute.org/publications/global-ordershadow-coronavirus-china-russia-and-west

Morse, Stephen S. 2007. Pandemic influenza: Studying the lessons of history. Proceedings of the National Academy of Sciences 104 (18), June 2007. Accessed February 19, 2021. https://www.researchgate.net/publication/6369245_Pandemic_influenza_Studying_the_lessons _of_history. 7313-7314

Rice, Condoleezza. 2020. COVID-19 and National Security, 14 April 2020. Hoover Policy Briefing. Accessed February 19, 2021. https://www.hoover.org/research/condoleezza-rice-covid-19-andnational-security

Simms, Chris. 2018. Pandemic response: fear is inevitable, panic is optional. Accessed February 22, 2021. https://cdn.dal.ca/content/dam/dalhousie/pdf/faculty/faculty-health-professions/healthadministration/Chris/Pandemic\%20response\%20fear\%20is\%20inevitable,\%20panic\%20option al.pdf

Signitzer, B., Wamser, C. 2006. Public diplomacy: A special governmental public relations function, in C. Botan, V. Hazleton, Eds., Public relations theory II, NJ: Lawrence Erlbaum Associates, Mahwah. 35-464.

Szicherle, Patrik, Krekó, Péter. 2020. Hungary: the Success Story of Chinese Mask Diplomacy, Center for Democrtic Integrity, August 3, 2020. Accessed February 20, 2021. https://democratic-integrity.eu/patrik-szicherle-peter-kreko-hungary-the-success-story-ofchinese-mask-diplomacy/

Varpahovskis, Eriks. 2020. Aid Diplomacy \& Nation Image: Central Asia and Russia. USC Center on Public Diplomacy. Jul 31, 2020. Accessed February 21, 2021.

https://uscpublicdiplomacy.org/blog/aid-diplomacy-nation-image-central-asia-and-russia

Verma, Raj. 2020. China's 'mask diplomacy' to change the COVID-19 narrative in Europe. Asia Eur J no. 18, 2020. Accessed February 21, 2021. https://link.springer.com/article/10.1007/s10308020-00576-1. 205-209.

Winter, Lisa. 2020. Chinese Officials Blame US Army for Coronavirus, in The Scientist, Mar 13, 2020. Accessed February 22, 2021. https://www.the-scientist.com/news-opinion/chinese-officialsblame-us-army-for-coronavirus-67267 